University of Rhode Island

DigitalCommons@URI

Open Access Master's Theses

1989

\title{
Analysis of Thiamin by Reverse Phase C18 Open Column Chromatography
}

Abdullah M. Alyabis

University of Rhode Island

Follow this and additional works at: https://digitalcommons.uri.edu/theses

\section{Recommended Citation}

Alyabis, Abdullah M., "Analysis of Thiamin by Reverse Phase C18 Open Column Chromatography" (1989). Open Access Master's Theses. Paper 1141.

https://digitalcommons.uri.edu/theses/1141

This Thesis is brought to you for free and open access by DigitalCommons@URI. It has been accepted for inclusion in Open Access Master's Theses by an authorized administrator of DigitalCommons@URI. For more information, please contact digitalcommons-group@uri.edu. 


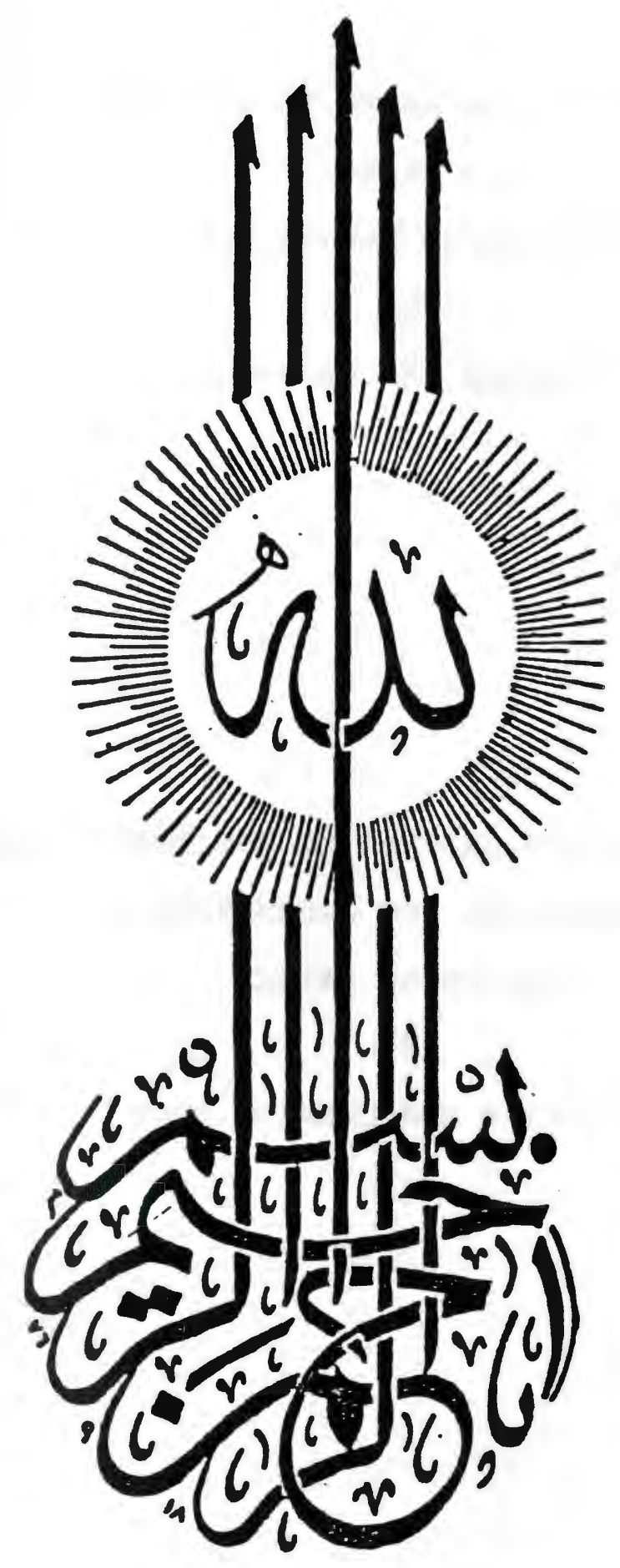




\author{
ANALYSIS OF THIAMIN BY REVERSE \\ PHASE $C_{18}$ \\ OPEN COLUMN CHROMATOGRAPHY \\ BY \\ ABDULLAH MA. ALYABIS
}

A THESIS SUBMITTED IN PARTIAL FULFILLMENT OF THE

REQUIREMENTS FOR THE DEGREE OF

MASTER OF SCIENCE

IN

FOOD SCIENCE AND NUTRITION

UNIVERSITY OF RHODE ISLAND

1989 


\section{MASTER OF SCIENCE THESIS \\ OF}

ABDULLAH MA. ALYABIS

APPROVED:

THESIS COMMITTEE

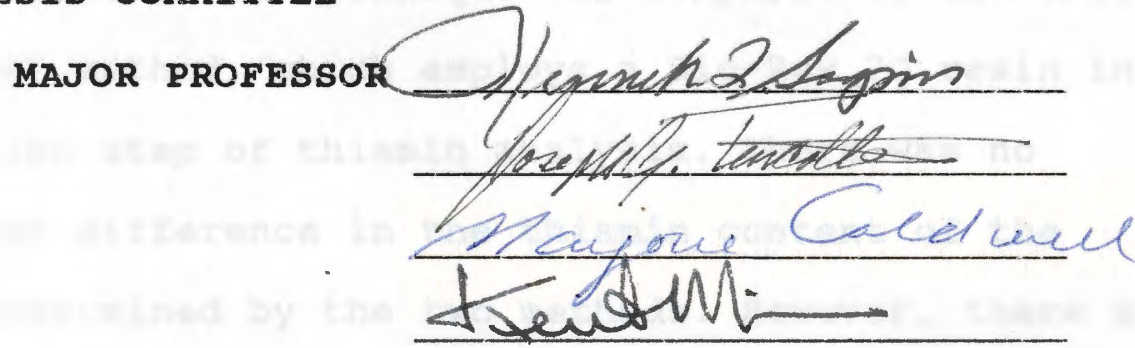

DEAN OF THE GRADUATE SCHOOL

UUNIVERSITY OF RHODE ISLAND

1989 


\section{ABSTRACT}

A modification of the AOAC method for thiamin determination utilizing reversed phase (RP) $C_{18}$ packing material was developed for analysis of milk, infant formula and breakfast cereal products. Thiamin was extracted from food samples and hydrolyzed following a similar Association of official Analytical Chemists (AOAC) (1984) procedure. The sample filtrate was purified by passing through the reversed phase $C_{18}$ column. An isocratic mobile phase consisting of $3 \% \mathrm{KCl}$ and methanol (70:30) was used to elute thiamin from the reversed phase $C_{18}$ column. The sample eluate was oxidized to thiochrome and quantified on a fluorometer using similar AOAC procedure.

The experimental technique was compared to the existing AOAC (1984) method, which employs a Bio-Rex 70 resin in the purification step of thiamin analysis. There was no significant difference in the thiamin content of the samples determined by the two methods. However, there was significant difference in the recovery of thiamin, when taken through the method or added to food samples before extraction. The recoveries of the added thiamin were 97.97 $\pm 0.69 \%$ and $92.67 \pm 1.25 \%$ for $\mathrm{RP} \mathrm{C}_{18}$ and $\mathrm{AOAC}$ (1984), respectively, the coefficient of variation was $0.70 \%$ and $1.34 \%$ for RP $C_{18}$ and AOAC (1984) methods respectively. 
(1984), respectively, the coefficient of variation was $0.70 \%$ and $1.34 \%$ for RP $C_{18}$ and AOAC (1984) methods respectively.

The RP $C_{18}$ method was found to be better than the AOAC (1984) method in terms of accuracy, precision, and reproducibility. And the $R P C_{18}$ proved to be faster than the AOAC ((1984) method. There was no difference in the cost of the two methods. Analysis for thiamin in the two infant formulas used in this study, gave values that were $132.37 \%$ and $202.90 \%$ of the declared levels, while thiamin content of breakfast cereal was $210.33 \%$ of the declared level. 


\section{ACKNOWLEDGEMENT}

I would like to express my appreciation to Dr. K. L. simpson for his guidance and encouragement throughout all phases of this research.

Thanks are also go to the members of my graduate committee, Dr. M. Caldwell, Dr. J. Turcotte and Dr. H. Gray for their suggestions.

Appreciation goes to my country for granting me a scholarship.

A special sincere appreciation goes to my family and my wife for their patience and faith in me during my academic study 


\section{PREFACE}

This thesis was written to conform with the Graduate school Manuscript thesis plan, following the Journal of Micronutrient Analysis. 
ABSTRACT ................................. ii

ACKNOWLEDGEMENT......................... iv PREFACE.................................

TABLE OF CONTENTS........................ vi

LIST OF TABLES.......................... vii

LIST OF FIGURES......................... viii

MANUSCRIPT

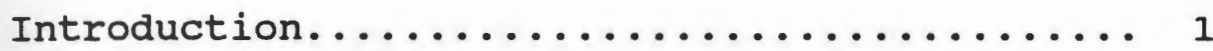

Materials and Methods................... 6

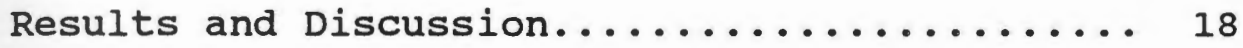

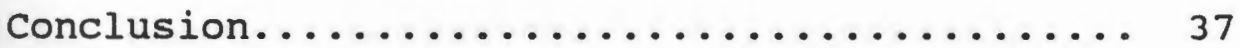

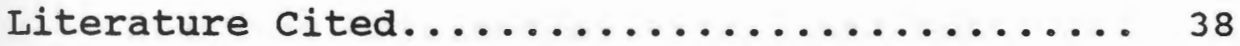

APPENDIX A

Literature Review.................. 47

Bibliography.......................... 57 


\section{LIST OF TABLES}

Page

TABLE 1. Thiamin content of milk, infant formula, and breakfast cereal as determined by

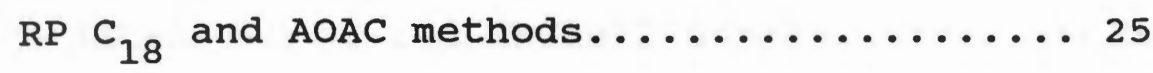

TABLE 2. Comparison of RP $C_{18}$ technique with

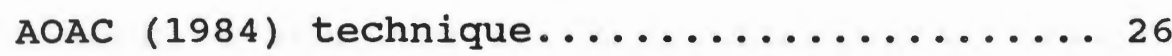

TABLE 3. Recovery percentage of added thiamin from milk, infant formula and breakfast cereal obtained by RP $\mathrm{C}_{18}$ and AOAC (1984)

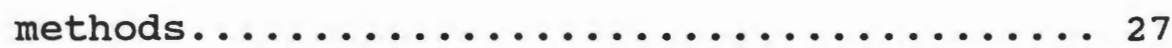

TABLE 4. Recovery percentage of thiamin working standard obtained by RP $C_{18}$ and AOAC

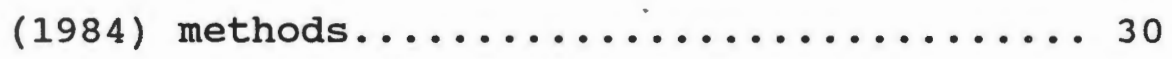

TABLE 5. Comparison of measured thiamin values by RP $C_{18}$ against nutritional label

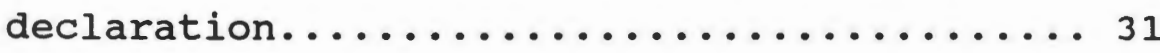

Table 6. Thiamin content of milk, infant formula and breakfast cereal products found

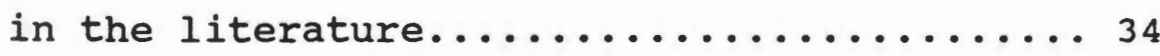




\section{IIST OF FIGURES}

Page

Figure 1. Effect of methanol on the Fluorescent intensity of the Enfamil sample........20

Figure 2. The standard curve of thiamin

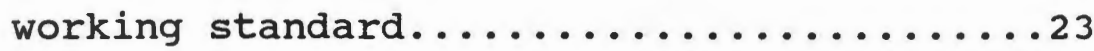

Figure A-1. Structures of thiamin and its related

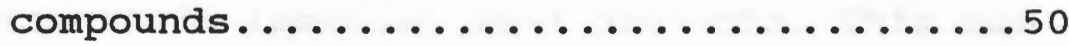




\section{INTRODUCTION}

Thiamin (vitamin $\mathrm{B}_{1}$ ) is an important nutrient in a human diet; it occurs in foods in either free or combined form; it is also added to some foods as an essential nutrient. Thiamin is required for the normal health and growth of humans.

The establishment of food labelling, in the last two decades, has resulted in a growing need for determination of micro-nutrients in labelled food products. This has created a need for methods that are fast, accurate, and applicable to different kinds of food matrices. Such methods should not require costly reagents or equipment, and should be suitable to both well and poorly equipped laboratories (Sebecic and Dragojevic, 1986).

Bioassay, microbiological, chemical and High Pressure Liquid Chromatography (HPLC) methods have been employed to determine thiamin content in food products. Biological methods are considered the reference standards for other methods because they determine the physiologically available vitamin rather than the total amount of vitamin present. The drawbacks of the biological methods are that 
they are time consuming, and costly. Thus chemical methods are the most used procedures today (Mauro and Wetzel, 1984).

The thiochrome method is the Association of official Analytical Chemists ( AOAC) (1984) approved method for the determination of thiamin content. The method involves a) acid extraction of thiamin and its phosphate esters, b) dephosphorylization of the extracted thiamin phosphate esters with phosphatase or diastase enzyme, c) purification, d) oxidation of thiamin to thiochrome under alkaline conditions, e) extraction of thiochrome by Isobutanol and fluorescence measurement. Purification of thiamin is carried out on Bio-Rex 70, a weakly acidic cation exchange resin, to separate thiamin from interfering substances.

Several researchers have recently reported the use of High Performance Liquid Chromatography (HPLC) to determine thiamin content in many food matrices, both alone (Ayi, et al., 1985; Botticher and Botticher, 1986; Hilker and Clifford, 1982; Hurst, et al., 1983; Kimura, et al., 1982; Ohta, et al., 1984) and combined with other water soluble vitamins (Ang and Moseley, 1980; Augustin, 1984; Fellman, et al., 1982; Fingals and Faulks, 1984; Kamman, et al., 
1980; Mauro and Wetzed, 1984; Skurray, 1981; Toma and Tabekhia, 1979; Wills, et al,. 1977; Wimalasiri and Wills, 1985). This technique has proved to have advantages over the official AOAC method in terms of sensitivity, specificity, accuracy and speed (Fellman, et al., 1982 ; Hilker and Clifford, 1982; Ohta, et al., 1984; Polsello and Rizzolo, 1986i), however the initial capital outlay and subsequent recurrent cost of maintaining the HPLC instrument are relatively high, and the equipment must be used by a skilled operator (Fingals and Faulks, 1987).

A comparison study (wills, et al., 1985) was made between HPLC, using a reverse phase $C_{18}$ column, and the AOAC (1980) methods for thiamin determination in different foods. The HPLC system gave thiamine values and recoveries which were $10 \%$ higher than those obtained by the AOAC procedure. Fingals and Faulks, (1984) determined thiamin in potatoes by the HPLC system, equipped with a reversed phase $C_{18}$ column, which gave a recovery value of $95.2 \%$, HPLC also gave higher thiamin values than those obtained by the AOAC fluorometric method.

Wehling and Wetzel, (1984) reported similar thiamin levels in fortified cereal products analyzed with HPLC, using a reversed phase $C_{18}$ column, and AOAC techniques. 
In another study (AYi, et al., 1985), the HPLC, with zorbax CN, $6 \mu \mathrm{m}$ column, and AOAC methods were utilized to determine vitamin $B_{1}$ content in infant formula products. The results obtained by both methods were in agreement with those obtained by Wehling and Wetzel, (1984). HPLC recovery studies yielded values of $100-102 \%$.

Hurst, et al., (1983) employed HPLC, with reversed phase $C_{18}$ column, and AOAC methods to measure the thiamin content in milk chocolate. The AOAC method gave results that were high when compared to HPLC figures. Fellman, et al., (1982) reported higher thiamin values obtained by the AOAC method when compared to HPLC values, using reversed phase $c_{18}$ column, from a number of foods.

This study examined the possibility of modifying the AOAC method for thiamin determination by replacing the Bio-Rex 70 resin used in the purification step of AOAC method with the reverse phase $c_{18}$ adsorbent ( $R P C_{18}$ ), which has been used in HPLC as the stationary phase by many investigators to separate and analyze thiamine in food matrices (Ellefson, 1985; Ellefson, et al., 1981; Fingals and Faulks, 1987; Fingals and Faulks, 1984; Kimura, et al., 1982; Mauro and Wetzed, 1984; Wills, et al., 1987; Wimalasiri and wills, 1985). This material was packed into an open column and used in the purification 
step of the AOAC procedure for thiamin analysis in milk, infant formula and breakfast cereal products.

The RP $C_{18}(50 \mu)$ packed into an open column has been used in this laboratory to separate carotene (Tsai et al, 1989) and retinol (Al-Abdulaly and Simpson, 1989) from various foods. Furthermore it was used to separate riboflavin, a water soluble vitamin, from milk and milk products (Saibu, 1988).

The results of this modified AOAC method will be compared with that of the official AOAC (1984) method in terms of cost, time, accuracy and recovery. The objective of this thesis is the development of a modified AOAC method for thiamin determination in food that is accurate and has the low cost and simplicity of the open column chromatography. 


\section{MATERIALS AND METHODS}

\section{samples:}

skim milk, whole milk, milk-based concentrate infant formulas a) Enfamil (Mead Johnson Nutritionals, IN) b) similac (Ross Laboratories, $\mathrm{OH}$ ) and a breakfast cereal (Kellogg's corn flakes fortified at $25 \%$ USRDA) were purchased from local supermarket.

\section{solvents:}

Isobutanol (Fisher Scientific, NJ) was redistilled in an all-glass apparatus. Methanol (Fisher Scientific, NJ), Chloroform (Fisher Scientific NJ), Nitric acid (Fisher Scientific NJ), Sulfuric acid (Fisher Scientific, NJ) and Hydrochloric acid (Fisher Scientific,NJ) all met ACS specifications.

\section{Equipment :}

- Fluorescence spectrophotometer ( Perkin-Elmer MPF 2A).

- Chromatographic columns:

- glass columns, with $50 \mathrm{ml}$ reservoir at top and a column ( $180 \mathrm{~mm}$ * $9 \mathrm{~mm}$ od.) drawn into a capillary at bottom, were used for Bio-Rex 70 packing.

- Glass columns, with $50 \mathrm{ml}$ reservoir at top and 
column (160 mm * $11.5 \mathrm{~mm}$ od.) drawn into a capillary at bottom, were used for RP $\mathrm{C}_{18}$ packing.

All glassware and pipets were acid washed with $6 \mathrm{~N}$ $\mathrm{HNO}_{3}$ to remove all interfering substances, and then rinsed with distilled water.

\section{Reagents:}

Deionized water was used to prepare all of the reagent solutions; all dilutions were carried out in volumetric glassware.

Reagents used were : Sodium hydroxide (Fisher Scientific, NJ), Thiamin hydrochloride (Fisher Scientific, NJ), Thiamin monophosphate chloride (Fluka, Switzerland), Thiamin pyrophosphate chloride (Pfaultz \& Bauer, CT), Quinine sulfate (Fluka, Switzerland), Potassium chloride (Sigma, MO), Taka-diastase (Pfaultz\& Bauer, CT), Sodium acetate (Sigma, MO), Papain (Sigma, MO), potassium ferricyanide (Baker, NJ), and Sodium Chloride (Sigma, MO). All reagents met ACS specifications.

Taka-diastase and papain were first tested before use to ensure that they are thiamin free.

Thiamin monophosphate and thiamin pyrophosphate standards, were treated with Taka-diastase and then their 
fluorescence was compared with that of thiamin standard. This was done to determine the capability of the enzyme in releasing thiamin from its phosphate esters.

\section{Preparation of Vitamin $B_{1}$ standard solutions:}

- stock thiamin standard: Thiamin hydrochloride was dried in oven at $100^{\circ} \mathrm{C}$ for two hours, to remove any $\mathrm{H}_{2} \mathrm{O}$ present. $0.1000 \mathrm{~g}$ of thiamin was dissolved in $0.14 \mathrm{~N} \mathrm{HCl}$ and diluted to 1 liter with the same. This solution was stored in a refrigerator at $4^{\circ} \mathrm{C}$.

- Intermediate thiamin standard: $5 \mathrm{ml}$ of stock standard was diluted to $250 \mathrm{ml}$ with $\mathrm{H}_{2} \mathrm{O}$.

\section{Preparation of Quinine sulfate solution:}

- Stock quinine sulfate solution: $100 \mathrm{mg}$ of quinine sulfate was dissolved in $0.1 \mathrm{~N} \mathrm{H}_{2} \mathrm{SO}_{4}$, and diluted to 1 liter with the same.

- Working quinine sulfate solution : $3 \mathrm{ml}$ of stock quinine sulfate solution was diluted to 1 liter with $0.1 \mathrm{~N}$ $\mathrm{H}_{2} \mathrm{SO}_{4}$ to give a final concentration of $0.3 \mathrm{mg} / \mathrm{L}$.

Alkaline potassium ferricyanide was prepared immediately prior to use by diluting four $\mathrm{ml}$ of $1 \%$ potassium ferricyanide to $100 \mathrm{ml}$ with. $15 \% \mathrm{NaOH}$; it was kept refrigerated in a brown bottle. 
Acid 25\% potassium chloride solution was prepared by dissolving $250 \mathrm{~g} \mathrm{~K} \mathrm{Cl}$ in $\mathrm{H}_{2} \mathrm{O}$ containing $8.5 \mathrm{ml}$ concentrated $\mathrm{H} \mathrm{Cl}$, and diluting to $1 \mathrm{~L}$ with $\mathrm{H}_{2} \mathrm{O}$.

\section{Yethods:}

All sample preparations were performed under subdued incandescent light.

Two methods for thiamin analysis were compared. Sample preparation, extraction, hydrolysis, oxidation to thiochrome and measurement on fluorometer were the same. The only difference between the two methods was in the purification step. The first one used the Reversed Phase $\mathrm{C}_{18} 50 \mu$ packing material (Separation Technology, Wakefield, RI). The second method used Bio-Rex 70 resin 50 - 100 mesh hydrogen form (Bio Rad Laboratories, CA), the material used in the official AOAC method (1984).

\section{Sample Extraction:}

A modified AOAC method was used for extraction, enzyme hydrolysis, and oxidation of the samples.

- Extraction and hydrolysis of skim and whole milk:

A $25 \mathrm{ml}$ prepared sample were put in $250 \mathrm{ml}$ Erlenmeyer flask. To the flask $50 \mathrm{ml} 0.14 \mathrm{~N} \mathrm{HCl}$ was added. The flask was covered with aluminum foil and 
autoclaved at $121^{\circ} \mathrm{C}$ for $15 \mathrm{~min}$. After cooling the extract to $50^{\circ} \mathrm{C}$ or lower, $5 \mathrm{ml}$ of $2.5 \mathrm{~N}$ NaOAC were added to adjust the $\mathrm{pH}$ to $4.5-5.0$, which is appropriate for the enzymes and five $\mathrm{ml}$ of freshly prepared enzyme suspension were added. The solution consisted of two enzymes, 1- $6 \%$ taka-diastase (phosphatase enzyme) to hydrolyze any phosphate esters of thiamin present to its free form. This step was necessary because thiochrome phosphates are not extracted by isobutyl alcohol (Hennessy and Cerecedo, 1939; Conner and Straub, 1941; Rindi and deGiuseppe, 1961; Clausen and Brown, 1943), and 2- 6\% papain (proteolytic enzyme) to release thiamin bound to protein. The contents of the flask were mixed and incubated at $47^{\circ} \mathrm{C}$ for $3 \mathrm{hrs}$ in a water bath, cooled to room temperature and transferred to a $100 \mathrm{ml}$ volumetric flask. The extracts were then mixed thoroughly and filtered through No. 40 whatman ash-free filter paper, which does not absorb thiamin, and the filtrate was stored in a refrigerator at $4^{\circ} \mathrm{C}$.

- Extraction of infant formula (Enfamil and similac):

Eight ml of infant formula concentrate were used. The samples were extracted and hydrolyzed the same way as skim and whole milk, except that only one enzyme, Taka-diastase, was used in the hydrolysis step. 
- Extraction of breakfast cereal (Rellogg's corn flakes): Inorder to facilitate the vitamin extraction the breakfast cereal was ground to a fine powder in a coffee beans grinder, to pass a 32 mesh screen. A 19 sample was used. It was extracted and hydrolyzed as above, except that only one enzyme, Taka-diastase, was used in the hydrolysis step.

- Extraction and hydrolysis of thiamin working standard:

To a $250 \mathrm{ml}$ Erlenmeyer flask, containing $45 \mathrm{ml} 0.14 \mathrm{~N}$ $\mathrm{HCl}$ and $5 \mathrm{ml} 2.5 \mathrm{~N}$ NaOAC, $5 \mathrm{ml}$ thiamin intermediate standard ( $2 \mathrm{ug} / \mathrm{ml})$ were added. It was extracted and hydrolyzed the same way as skim and whole milk, except that only Taka-diastase was used in the hydrolysis step.

\section{Purification through the RP $\mathrm{C}_{18}$ column:}

A glass chromatography column, fitted with a $50 \mathrm{ml}$ reservoir at the top and a column $(160 \mathrm{~mm}$ long * $11.5 \mathrm{ml}$ od.) drawn into a capillary at bottom was used, It was fitted with a piece of glass wool, placed over the upper end of the capillary. The column was packed with RP $C_{18}$ to a height of $6 \mathrm{~cm}$. The surface of the stationary phase was covered with another piece of glass wool. Nitrogen gas was used to control column flow rate, which was $1 \mathrm{ml} /$ min. or less. Different mixtures of solvents were examined 
to choose the right mobile phase to elute thiamin from the RP $C_{18}$ column.

The RP $\mathrm{C}_{18}$ column was prewetted with $\mathrm{MeOH}: \mathrm{H}_{2} \mathrm{O}$ $(70: 30)$. Five $\mathrm{ml}$ of sample filtrate were passed through the column. and eluted with $3 \% \mathrm{KCl}: \mathrm{MeOH}(70: 30)$. The second $10 \mathrm{ml}$ eluate was collected and evaporated to near dryness under vacuum in a rotary evaporator. After evaporation, the residues was rehydrated and transferred to a $10 \mathrm{ml}$ volumetric flask.

In another RP $C_{18}$ column, $5 \mathrm{ml}$ thiamin working standard filtrate were run through the column in the manner described above.

The RP $\mathrm{C}_{18}$ packed in the column was cleaned after elution with mixture of chloroform : methanol (60:40), and then rinsed with a mixture of methanol : water (70 :30).

\section{Purification through the Bio-Rex 70 resin:}

A glass column, fitted with $50 \mathrm{ml}$ reservoir at top and a column (180 mm long * $9 \mathrm{~mm}$ od) drawn into a capillary at bottom, was fitted with a piece of glass wool placed over upper end of capillary. It was packed with Bio-Rex 70 
resin to a height of $10 \mathrm{~cm}$. The flow rate was $1 \mathrm{ml} / \mathrm{min}$, it was controlled by attaching polyethylene tube with metal clamps to the tip of capillary and adjusting the dial for flow rate.

A $10 \mathrm{ml}$ sample filtrate was pipetted into the Bio-Rex 70 column. The filtrate was discarded, the column and reservoir were washed with three $5 \mathrm{ml}$ portions of hot $\mathrm{H}_{2} \mathrm{O}\left(63^{\circ} \mathrm{C}\right)$, and the eluate was also discarded. Thiamin was eluted from the resin by passing five $4.5 \mathrm{ml}$ portions of hot $\left(63^{\circ} \mathrm{C}\right)$ acid- $25 \% \mathrm{KCl}$ solution through the column. The eluate was collected into a $25 \mathrm{ml}$ volumetric flask, cooled and diluted to volume with acid-25\% $\mathrm{KCl}$ solution.

In another Bio-Rex 70 column $10 \mathrm{ml}$ thiamin working standard filtrate were run through the resin as above.

The Bio-Rex 70 resin packed in the column was washed between runs with $1 \mathrm{~N} \mathrm{HCl}$, rinsed with deionized water, re-equiliberated by depacking the resin, and then placed in a beaker to be stirred with deionized water for $1 \mathrm{~min}$ before decanting. $\mathrm{H}_{2} \mathrm{O}$ washes were repeated until excess acid had been removed. The resin was repacked in the column (Guide to Ion Exchange, Bio Rad). 


\section{conversion to thiochrome:}

To each of two $35 \mathrm{ml}$ centrifuge tubes, $1.5 \mathrm{~g} \mathrm{NaCl}$ and $5 \mathrm{ml}$ of sample eluate were added. To the first centrifuge tube, $3 \mathrm{ml}$ of the oxidizing reagent ( $1 \%$ alkaline ferricyanide solution) were added. The tube was swirled to ensure adequate mixing. Immediately, $11 \mathrm{ml}$ isobutanol were added. The tube was stoppered and shaken vigorously for 90 sec. Thiamin is oxidized to thiochrome by potassium ferricyanide in the presence of strong alkali (Jansen, 1936; Kinnersley, et al., 1935; Hennessy and Cerecedo, 1939; Rosenberg, 1942). Thiochrome is soluble in isobutyl alcohol.

The second centrifuge tube (sample blank) was treated similarly, except that the oxidizing reagent was replaced with a $15 \% \mathrm{NaOH}$ solution.

To each of another 2 centrifuge tubes, $1.5 \mathrm{~g} \mathrm{NaCl}$ and $5 \mathrm{ml}$ thiamin working standard eluate were added. These tubes were treated in the same manner as mentioned above for the tubes containing the sample eluate. After the addition of isobutanol to all tubes, the tubes were shaken again for $2 \mathrm{~min}$ in a shaker box then centrifuged for 1 min.

\section{Measurement of thiochrome:}

Thiochrome fluorescence was measured on the 
fluorometer. Excitation and emission wavelengths were 365 $\mathrm{nm}$ and $425 \mathrm{~nm}$ respectively. Quinine sulfate standard was used to check the reproducibility of the fluorometer. Thiamin content of the oxidized sample filtrate solution was determined by comparing fluorescence intensity of sample eluate with that from oxidized working standard eluate.

- Thiamin content of the sample was calculated as follows:

$$
\begin{aligned}
& \begin{array}{ll}
S-S B & 100
\end{array} \\
& \longrightarrow \text { - } ~ C x \\
& \text { ST -STB SW }
\end{aligned}
$$

Where:

$$
\begin{aligned}
S & =\% \text { Transmittance of the sample; } \\
\text { SB } & =\% \text { Transmittance of the sample blank; } \\
\text { ST } & =\% \text { Transmittance of the standard; } \\
\text { STB } & =\% \text { Transmittance of the standard blank; } \\
C & =\text { Concentration of the standard; } \\
100 & =\text { Total volume of original sample; } \\
\text { SW } & =\text { Sample weight } ;
\end{aligned}
$$

\section{Recovery method :}

In the recovery studies of the $\mathrm{RP} \mathrm{C}_{18}$ and Bio-Rex 70 
columns, the same extraction and hydrolyzation procedures used. However, $5 \mathrm{ml}$ of thiamin intermediate standard (2 $\mathrm{ug} / \mathrm{ml}$ ) was added to the prepared samples prior to autoclaving. The filtrate of all the recovery samples were run through RP $\mathrm{C}_{18}$ or Bio-Rex 70 columns. Recovery sample eluates were oxidized to thiochrome and measured on fluorometer in the same manner as other assay samples.

The percent recovery of the method was calculated by substracting the corrected spiked sample reading from the corrected reading of sample alone. The difference was compared with the reading of oxidized thiamin working standard that bypassed the purification step.

The percentage recovery of the method was calculated as follows:

$$
\frac{[(R S-R S B)-(S-S B)] \times D F}{\text { WST }- \text { WSTB }} \times 100=\%
$$

Where:

$$
\begin{aligned}
\text { RS } & =\% \text { Transmittance of spiked sample; } \\
\text { RSB } & =\% \text { Transmittance of spiked sample blank; } \\
\text { S } & =\% \text { Transmittance of sample; } \\
\text { SB } & =\% \text { Transmittance of sample blank; } \\
\text { DF } & =\text { Dilution factor }
\end{aligned}
$$




$$
\begin{aligned}
\text { WST }= & \% \text { Transmittance of working standard that } \\
& \text { bypassed purification; } \\
\text { WSTB }= & \% \text { Transmittance of working standard blank that } \\
& \text { bypassed purification; }
\end{aligned}
$$

column recovery:

The eluted working standards of both methods were checked against one that had bypassed the purification step. Fluorescence of both standards were compared and the recovery through the column was calculated as follow:

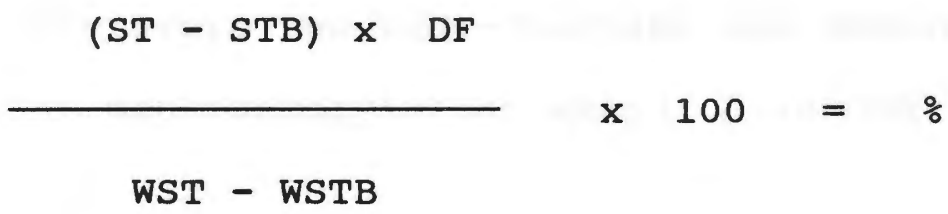

Where:

$$
\begin{aligned}
\text { ST }= & \% \text { Transmittance of the standard; } \\
\text { STB }= & \% \text { Transmittance of the standard blank; } \\
\text { DF }= & \text { Dilution factor; } \\
\text { WST }= & \% \text { Transmittance of working standard that } \\
& \text { bypassed purification; } \\
\text { WSTB = } & \% \text { Transmittance of working standard blank } \\
& \text { that bypassed purification; }
\end{aligned}
$$

\section{Statistics:}

The results of the RP $\mathrm{C}_{18}$ and Bio-Rex 70 methods were expressed as mean $\pm S D$ and compared using the t-test. 


\section{RESULTS AND DISCUSSION}

The thiamin standard was first checked by UV/VIS absorption to confirm its purity. The resultant spectrum was found to be the same as documented in the literature.

The Taka-diastase and Papain were proved to be thiamin free. Taka-diastase was found effective in releasing phosphates from thiamin. The recoveries were $94 \%$ and $95 \%$ from thiamin monophosphate and thiamin pyrophosphate respectively. Therefore the Taka-diastase was considered suitable for the dephosphorylation step (Ellefson, 1985).

The sample eluted from the RP $C_{18}$ column was evaporated to near dryness to remove methanol present in the mobile phase ( $3 \% \mathrm{KCl}$ : methanol $70: 30)$. Methanol was found to increase the fluorescent intensity of the sample, resulting in higher and inaccurate thiamin content calculation. Figure 1 shows the fluorescence spectrum of the Enfamil sample, eluted from the RP $C_{18}$ column, (a) after evaporation and (b) without evaporation. These spectrums clearly demonstrate the methanol effect on thiamin measurements (there was a $10 \%$ increase). 
Figure 1 Fluorescence spectrum of Enfamil infant formula sample that was passed through the RP $C_{18}$ column: (A) After evaporation and dilution with $\mathrm{H}_{2} \mathrm{O}$ only. (B) Without evaporation. 
(A)

(B)

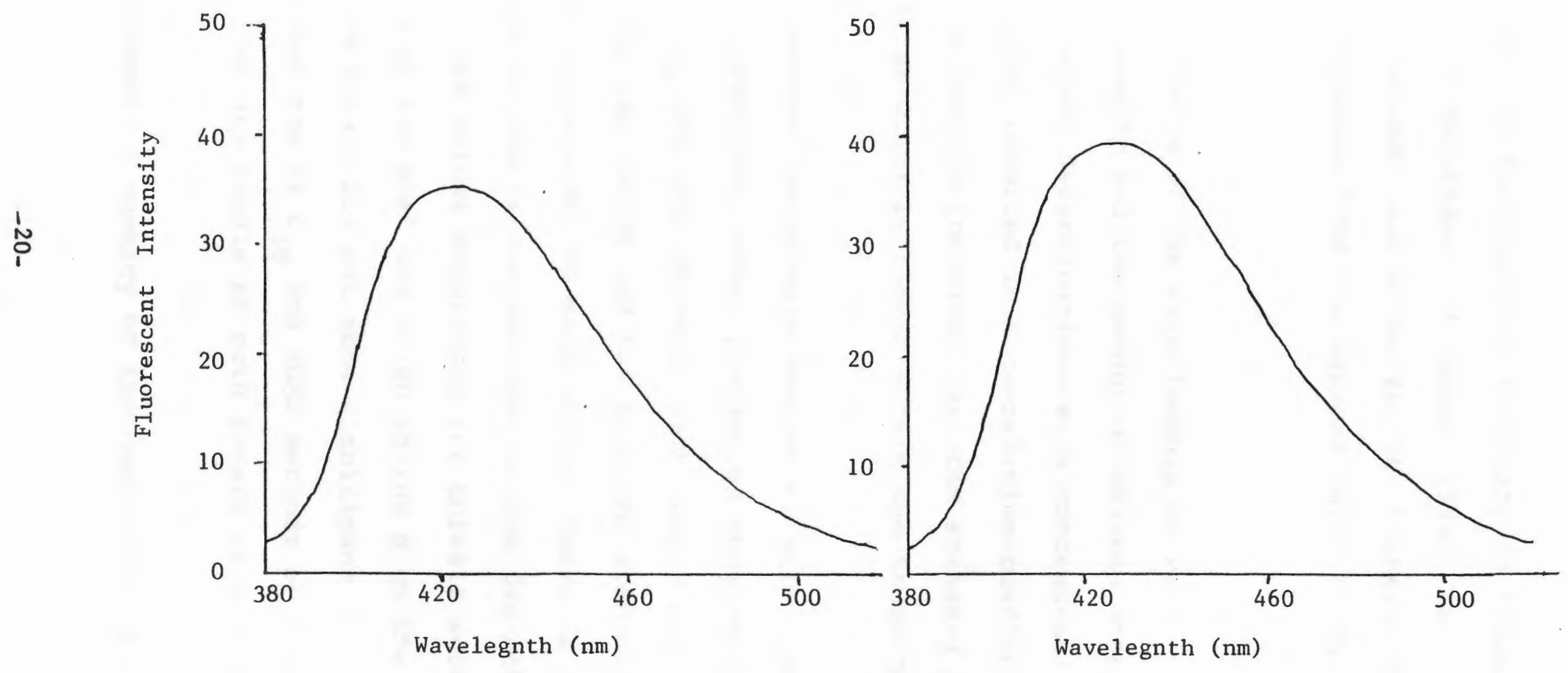


Methanol's effect on fluorescence intensity of thiamin was first reported by McFarlane and Chapman (1941) who suggested that methanol may stimulate the transfer of interfering substances from the aqueous layer to the isobutanol layer.

Linear regression of the relationship between fluorescent intensity and the amount of thiamin standard from seven different determinations at a concentration of 0.00 to $0.25 \mu \mathrm{g} / \mathrm{ml}$ resulted in a correlation coefficient of 0.998 . These results indicated that the standard curve (figure 2) was practically linear within the range tested.

Table 1 presents the thiamin content of milk, infant formula, and a breakfast cereal product as measured by the reverse phase $\mathrm{C}_{18}$ and AOAC methods. Each sample was analyzed in four replicates and the mean and standard deviation were calculated for each method. There is a close agreement in the values obtained by the two methods. As an example, the values determined for Enfamil were $67.95 \mu \mathrm{g} / 100 \mathrm{~g}$ by the $\mathrm{AOAC}$ and $67.60 \mu \mathrm{g} / 100 \mathrm{~g}$ by the RP $\mathrm{C}_{18}$ method. The t-test did not show significant variation between the RP $\mathrm{C}_{18}$ and AOAC methods of thiamin determination for any sample at both levels of $5 \%$ and $1 \%$ probability.

Table 2 presents a summary of the comparison of 
Figure 2 standard curve of thiamin working standard. Different concentrations of thiamin standard from 0.00 to $0.25 \mu \mathrm{g} / \mathrm{ml}$, measured by Perkin-Elmer MPF $2 \mathrm{~A}$ Fluorometer. (EX. $365 \mathrm{~nm}$, EM. $425 \mathrm{~nm}$ ). 


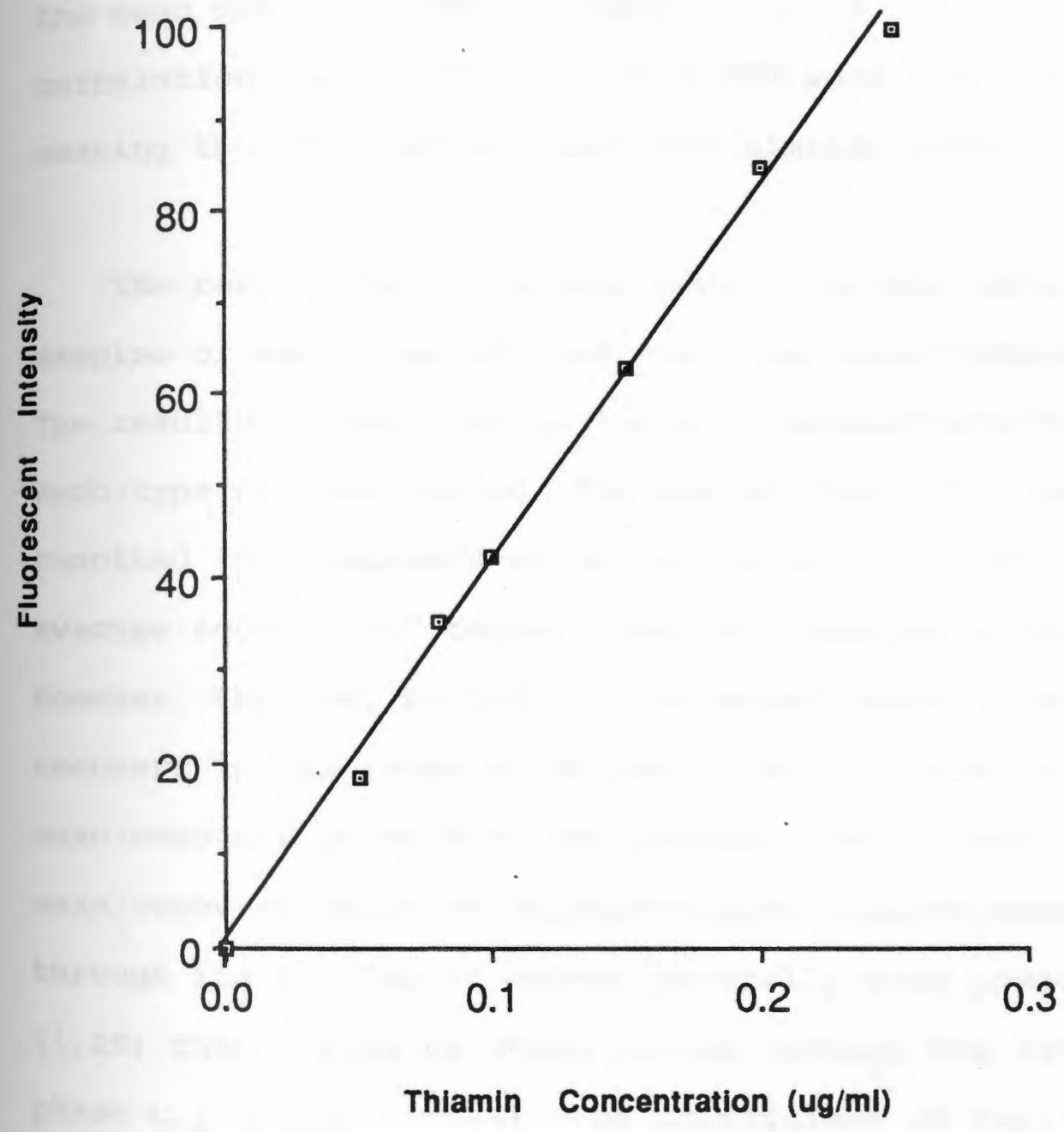


thiamin values in foods attained by the RP $C_{18}$ column technique over those acquired by the Bio Rex 70 column technique. The results gave a mean value of 0.999 , showing that the two methods are comparable. The standard deviation of 0.018 , the coefficient of variation (C.V.) of the mean ratio of results equal to $1.8 \%$, and a correlation coefficient $(r)$ of 0.999 were obtained, meaning that the two methods gave similar results.

The recoveries of thiamin added to four replicate samples of each type of food analyzed, were determined. The results, summarized in Table 3 , demonstrate that, for each type of food tested, the use of the RP $C_{18}$ method resulted in a recovery of $96.64 \%$ to $98.57 \%$, with an average recovery of thiamin over all samples of $97.97 \%$. However, the AOAC method, in our experiments, yielded a recovery in the range of $90.89 \%$ to $94.55 \%$, with an overall mean recovery of $92.67 \%$. The standard deviations of the mean recovery value of thiamin-spiked samples passed through the Bio Rex 70 column generally were greater (1.25) than values of those passed through the reversed phase $c_{18}$ column $(0.69)$. The coefficient of variation for the two methods were 0.70 and 1.34 by the RP $C_{18}$ and AOAC techniques respectively. The recovery difference between the two methods were statistically significant at levels of both $5 \%$ and $1 \%$ probability. 


$$
\begin{aligned}
& \text { Table 1. Thiamin content of Milk, } \\
& \text { Infant Formula, and Breakfast cereal } \\
& \text { products determined by AOAC and } \\
& \text { Reverse Phase } C_{18} \text { methods. }
\end{aligned}
$$

Skim milk

Whole milk

Similac

Enfamil

Corn flakes

breakfast cereal

$$
2768 \pm 44
$$

$37.16 \pm 0.60$ $38.14 \pm 1.17$ $132.86 \pm 1.27$ $67.60 \pm 0.51$ (25\% USRDA)

* average $\pm S D$. for four replicates analyses. 
Table 2. Comparison of Reverse Phase $C_{18}$ column technique with AOAC technique.

Product
Vitamin $B_{1}$ values

$$
\text { RP } c_{18} / \text { AOAC }
$$
Skim milk
1.025
Whole milk
1.014
Similac
0.976
Enfamil
0.995
Corn flakes
breakfast cereal
0.989
$\mathrm{x}$
0.999
SD
0.018
CV
$1.8 \%$
r
0.999 
Table 3. Recovery percentage of added thiamin from milk, infant formula, and breakfast cereal products obtained by RP $C_{18}$ and AOAC methods.

Product

AOAC

$\mathrm{RPC}_{18}$

$\begin{array}{llr}\text { Skim milk } & 93.13 \pm 1.38^{*} & 96.64 \pm 1.56 \\ \text { Whole milk } & 91.79 \pm 2.09 & 98.57 \pm 0.89 \\ \text { Similac } & 90.89 \pm 1.64 & 98.29 \pm 1.72 \\ \text { Enfamil } & 94.55 \pm 1.08 & 98.06 \pm 0.72\end{array}$

Corn flakes

breakfast cereal

$92.97 \pm 0.65$

$98.30 \pm 1.00$

$\begin{array}{lrr}X & 92.67 & 97.97 \\ S D & \pm 1.25 & \pm 0.69 \\ \text { C.V. } & 1.34 \% & 0.70 \%\end{array}$

* average $\pm S D$ for four replicates analyses. 
Using the AOAC method, with Decalso resin in the purification step, Pippin and Potter (1975), obtained recoveries in the range of $87 \%$ to $90 \%$ for samples containing different levels of thiamin. They attributed the majority of losses to incomplete adsorption and/or elution of thiamin during purification on the ion exchange resin. Wills et al (1985) reported recovery rates for the AOAC procedure ranging from $86.1 \%$ to $92.8 \%$, with a mean recovery value of about $90 \%$.

The recovery data suggest that lower losses of thiamin occurred in the Reversed Phase $C_{18}$ method than in the AOAC method. In evaluating the two methods, all the steps were the same except for the purification step. This step may be where the recovery losses of the AOAC method occurred.

The accuracy and precision of the two methods can be expressed in terms of recovery and standard deviation respectively. Thus it can be suggested that the reverse phase $C_{18}$ is more accurate and precise than the AOAC method.

A measurement of reproducibility of the two methods was performed using thiamin working standard, by running 
the same standard four times through each column. The results of this measurement are represented in Table 4 .

The data shown in table 4 agree well with those of the recovery samples (Table 3 ). The t-test did show significant difference between the values of the two methods at $1 \%$ probability. The average recovery value of the two columns were $98.47 \%$ and $94.23 \%$ for the RP $C_{18}$ and Bio Rex 70 columns respectively. The standard deviation of the mean recovery percentage of thiamin standard eluted from the reverse phase $C_{18}$ column was smaller $(0.20)$ than for that of thiamin standard passed through the Bio Rex 70 column (0.73). The coefficient of variation were $0.20 \%$ and $0.77 \%$ for the reversed phase $C_{18}$ and Bio Rex 70 columns respectively. These values indicate that the $\mathrm{Rp}$ $C_{18}$ method yielded more reproducible results than the AOAC method.

The vitamin $B_{1}$ values, as declared on labels of the food products and as measured by the reverse phase $c_{18}$ technique are represented in Table 5. It appears from these values that for skim and whole milk, the declared and determined values are similar. However, the other samples showed large differences in thiamin content between the declared and determined values. Both infant 
Table 4. Recovery percentage of thiamin working standard obtained by RP $C_{18}$ and AOAC methods.

sample

AOAC

$\operatorname{RP} C_{18}$

1

$93.63 \pm 0.95^{*}$

$93.96 \pm 1.30$

$95.50 \pm 0.98$

$94.56 \pm 0.75$

$93.52 \pm 1.82$
$98.56 \pm 0.68$

$98.80 \pm 0.78$

$98.24 \pm 0.84$

$98.35 \pm 0.94$

$98.39 \pm 1.32$
$\mathrm{X}$

SD

CV
94.23

0.73

$0.77 \%$
98.47

0.20

$0.20 \%$

* average \pm SD for four replicates analyses. 
Table 5. Comparison of measured thiamin values by RP $C_{18}$ against nutritional label declaration.

Product

$$
\text { Vitamin } B_{1} \text { content }(\mu \mathrm{g} / 100 \mathrm{~g})
$$

$\because$ of the declared

Measured

Declared level

Skim milk

Whole milk

Enfamil

Similac

Corn flakes

breakfast cereal
37.16

38.14

67.60

132.9

2738

1302

210.3 
formula products produced unusually high values, although the difference was more pronounced in the similac sample. The percentage of label declaration value for Enfamil and similac were $132.4 \%$ and $209.1 \%$ respectively. The difference observed between the two formulas is significant at the $1 \%$ probability.

The thiamin levels exceeded the minimum requirements of the Infant Formula Act (1980) ( $40 \mu \mathrm{g} / 100 \mathrm{~K} \mathrm{Cal}=$ $26.19 \mu \mathrm{g} / 100 \mathrm{~g})$. This Act does not specify maximum limits for the vitamin. The infant formulas used in this study were concentrated liquid prepared from a nonfat milk base. The declared levels were $51.07 \mu \mathrm{g} / 100 \mathrm{~g}$ and $65.48 \mu \mathrm{g} / 100 \mathrm{~g}$ for Enfamil and Similac respectively, while the measured levels were $67.60 \mu \mathrm{g} / 100 \mathrm{~g}$ and $132.9 \mu \mathrm{g} / 100 \mathrm{~g}$ for Enfamil and Similac repectively. This difference between the declared and merasured levels was expected since other authors reported high levels of thiamin in infant formula. Ayi et al, (1985) determined the thiamin content in infant formula products by the HPLC and AOAC (1980) methods. The two methods gave comparable values. Vitamin $B_{1}$ levels in these products ranged from 122 to $216 \%$ of the declared levels. Also these results are in agreement with the values obtained by Martin et al, (1987), who determined thiamin content in $76 \mathrm{milk}$ and soy based infant formula 
samples. Thiamin contents were found to be $172.2 \% \pm 52.8 \%$ of label declaration.

The breakfast cereal sample showed a large difference between vitamin $B_{1}$ values measured and that calculated from the information on the label. The percentage found was $210.3 \%$ of the declared level. Vanderslice and Huang (1986) found thiamin in breakfast cereal to be $171 \%$ of the value declared on the label. This was further supported by the findings of Hilker and Clifford (1982), They determined the thiamin content to be $141 \%$ of the declared level on the breakfast cereal label.

Thiamin has particular stability problems. Heat causes thiamin losses during the production process. So the manufacturers of the fortified products must take into account potential losses that may happen during the processing and storage of the product. Accordingly, declared levels can be lower than the amount present in the product (Martin et al, 1987).

Table 6 presents vitamin $B_{1}$ values in milk, infant formula, and breakfast cereal products reported in the literature. The results obtained in this investigation (Table 1) and the levels reported by other researchers are 
Table 6. Thiamin content of Milk, Infant Formula, and Breakfast cereal products found in the literature.

Product

vitamin $B_{1}$

Reference

content $(\mu \mathrm{g} / 100 \mathrm{~g})$

skim milk

Whole milk

Whole milk

Whole milk

Infant formula

Breakfast cereal

(25\% USRDA)

Breakfast cereal (25\% USRDA)
36

38

$$
33-37
$$

39.24

$66-137$

$106.5 \pm 39.7$

Agriculture handbook

$$
\text { No. 8-1 (1976) }
$$

Agriculture Handbook

$$
\text { No. 8-1 (1976) }
$$

Skurray (1981)

Halliday and Deuel

(1941)

Ayi et al, (1985)

Martin et al,

(1987)

$1080-1120 \quad$ Skurray (1981)

$1150-1360$ Kamman et al, (1980) 
in agreement except for the corn flakes breakfast cereal.

The time required for the sample purification through the reversed phase $\mathrm{C}_{18}$ column was $20 \mathrm{~min}$. Another $15 \mathrm{~min}$ were needed for the evaporation and dilution of the eluate, while the time required for the purification through the Bio Rex 70 column was $50 \mathrm{~min}$. From this comparison we can notice that reverse phase $C_{18}$ column reduced the time required for sample purification by 15 $\min$.

In the regeneration and re-equiliberation process of the Bio Rex 70 column, the packing material must be unpacked, re-equiliberated in a beaker and then repacked again (BIO Rad). This process will consume some time, especially if there are many samples to be analyzed in the same day. However, the reverse phase $c_{18}$ packing material can be cleaned without unpacking from the column, which is another advantage of the reverse phase $c_{18}$ method.

The RP $\mathrm{C}_{18}$ packing material cost is higher than that of the Bio Rex 70 resin (The cost of $100 \mathrm{~g} \mathrm{RP} \mathrm{C_{18 }}$ packing material is $200 \$$, while the cost of the same amount of Bio-Rex 70 resin is 47 \$). However, the Bio Rex 
70 resin showed a decrease in efficiency after several samples had been run through the resin. Hence the column must be packed with a new packing material. The reverse phase $c_{18}$ packing material gave good results throughout a large number of runs when it was cleaned between runs. Therefore the cost of packing material of the two methods seems comparabele.

The mobile phase cost of the reverse phase column is equal or less than that of the Bio Rex 70 column $(6.5$ cents per run for Bio Rex 70 compared to 2 cents per run for $\mathrm{RP} \mathrm{C}_{18}$ ).

From the above discussion we can note that the reverse phase $C_{18}$ method reduces the time and cost of thiamin analysis comparing to the AOAC (1984) method. 


\section{CONCLUSION}

In conclusion, the use of reverse phase $C_{18}$ packing material in the purification step of the AOAC (1984) method for thiamin determination in milk, infant formula and a breakfast cereal product resulted in a modified of the AOAC method. This method has the advantages of HPLC in terms of accuracy and precision, and the simplicity and low cost of open column chromatography. This method is faster, more accurate, precise and reproducible when compared to the existing AOAC method. This method can be employed in laboratories which do not have the HPLC instrument or where it used to perform analyses other than thiamin. 


\section{IITERATURE CITED}

Agricultural Research Service, (1976). Composition of Foods, Agricultural Handbook No. 8-1, Consumer and Food Economics Institute, Agricultural Resaerch Service USDA, Washignton D.C.

Al-Abdulaly, A. B., \& Simpson, K. L., (1989). Reversed-phase flash column chromatography for the determination of retinol in some foods. J. Micronutr. Anal. 5, 161-69.

Ang, C. Y. W., \& Moseley, F. A., (1980). Determination of thiamin and riboflavin in meat and meat products by HPLC. J. Agric. Food Chem., 28, 483-86.

AOAC. (1984). Official Methods of Analysis (14th ed.), Assoc. Off. Anal. Chem. Arlington, VA., 43.024-43.029.

Augustin, J.,(1984). Simultaneous determination of thiamin and riboflavin in foods by liquid chromatography. J. Assoc. Off. Anal. Chem. 67, 1012-15.

Ayi, B. K., Yuhas, D. M., Moffett, K. S., Joyce, D. M., \& 
Deangelis, N. J., (1985). Liquid chromatography determination of thiamin in infant formula products by using Ultraviolet detection. J. Assoc. Off. Anal. Chem. $68,1087-92$.

Bio Rad, Guide to ion exchange, Catalog No. 140-9997. Bio Rad Laboratories, Richmond, CA.

Botticher, B., \& Botticher, D., (1986). Simple rapid determination of thiamin by HPLC method in foods, body fluids, Urine and faeces. Int. J. Vit. Res., 56, 155-59.

Clausen, D. F., \& Brown, R. E., (1943). Determination of thiamin in bread by the thiochrome method. Ind. Eng. Chem. Anal. Ed., 15, 100-101.

Conner, R. T., \& Straub, G. J., (1941). Determination of thiamin by thiochrome reaction. Ind. Eng. Chem. Anal. Ed., $13,380-84$.

Ellefson, W. C., (1985). "Thiamin", in Methods of vitamin assay, 4th. Ed. J. Augustin et al. Editors, John WILEY \& sons. p. 349-63.

Ellefson, W. C., Richter, E., Adams, M., \& Baillies, N. 
H., (1981). Evaluation of ion exchange resins and various enzymes in thiamin analysis. J. Assoc. Off. Anal. Chem., $64,1336-38$.

Fellman, J. K., Artz, W. E., Tassinari, P. D., Cole, C. L., \& Augustin, J., (1982). Simultaneous determination of thiamin and riboflavin in selected foods by high performance liquid chromatography. J. Food Sci., 47, 2048-50.

Fingals, P. M., \& Faulks, R. M., (1987). Critical review of HPLC methods for the determination of thiamin, riboflavin and niacin in food. J. Micronutr. Anal., 3, 251-83.

Fingals , P. M., \& Faulks, R. M., (1984). The HPLC analysis of thiamin and riboflavin in potatoes. Food Chem. , 15, 37-44.

Halliday, N., \& Deuel, H., (1941). The presence of free and combined thiamin in milk. J. Biol. Chem., 140, 55-61.

Hennessy, D. J., \& Cerecedo, L. R., (1939). The determination of free and phosphorylated thiamin by a modified thiochrome assay. J. Am. Chem. Soc. 61, 179-83. 
Hilker, D. M., \& Clifford, A. J., (1982). Thiamin analysis and separation of thiamin phosphate esters by high performance Iiquid chromatography. J. Chromatogr., 231, $433-438$.

Hurst, W. J., Mckim, J. M., \& Martin, R. A., (1983). The HPLC analysis of thiamin in milk chocolate. Int. J. vit. Res., 53, 239-42.

Jansen, B. C. P., (1936). A chemical determination of aneurin (vitamin $B_{1}$ ) by the thiochrome reaction. Rec. Trav. Chim., 55, 1046-52.

Kamman, J. F., Labuza, T. P., \& Warthesen, J. J., (1980) . Thiamin and riboflavin analysis by high performance liquid chromatography. J. Food Sci., 45, 1497-99.

Kimura, M., Panijpan, B., \& Itokawa, Y., (1982). Separation and determination of thiamin and its phosphate esters by reversed phase high performance liquid chromatography. J . Chromatogr., 245, 141-43.

Kinnersley, H. W., O Brien, J. R., \& Peters, R. A., (1935). The properities of blue fluorescent substances formed by oxidation of vitamin $B_{1}$ (quinochromes). 
Biochem. J., 29, 2369-84.

Martin, J. I., Phifer, E. C., Hines, D. M., Hamill, T. W., young, E. R., Eitenmiller, R. R., \& Soliman, A. M., (1987). Thiamin, riboflavin and ascorbic acid levels in infant formulas manufactured in the United States. J. Food Comp. Anal., 1, 76-80.

Mauro, D. J., \& Wetzed, D. L., (1984). Simultaneous determination of thiamin and riboflavin in enriched cereal based products by high performance liquid chromatography using selective detection. J. Chromatogr., $299,281-87$.

McFarlane, W. D., \& Chapman, R. A., (1941). An improved thiochrome method for the determination of vitamin $B_{1}$. Can. J. Res., 19B, 136-42.

National Research Council, (1989). Recommended Dietary Allowances, 10th ed., Commitee on Dietary Allowances, Food and Nutrition Board, Commission on Life Sciences, National Research Council, National Academy Press, Washignton D.C.

Ohta, H., Baba, T., \& Suzuki, Y., (1984). High performance liquid chromatographic analysis of thiamin in rice flour with flourimetric post column derivatization. J. 
Chromatogr., 284, 281-84.

Pippen, E. L., \& Potter, A. L., (1975). Quantitating the recovery of thiamin (Vitamin $B_{1}$ ) from Decalso in the thiochrome method for the determination thiamin. J. Agric. Food Chem., 23, 523-26.

Polsello, A., \& Rizzolo, A., (1986). Applications of HPLC to the determination of water-soluble vitamins in foods. (a Review 1981-1985) J. Micronutr. Anal., 2, 153-87.

Rindi, G., \& DeGuiseppo, L., (1961). A new chromatographic method for the determination of thiamin and its mono-, diand tri-phosphates in animal tissues. Biochem. J., 78, 602-06.

Rosenberg, h. R., (1942). Chemistry and physiology of the vitamins. Interscience, New York, p. 99-150.

Saibu L. O., (1988). Development of a revese-phase open column method of quantifying riboflavin in milk. M.S. thesis. Department of food science and nutrition at URI.

Sebecic, B., \& Dragojevic, I. V., (1986). An improved simple procedure for the determination of thiamin in food. 
Die Nahrung., 5, 527-32.

skurray, G. R., (1981). A rapid method for selectively determining small amounts of niacin, riboflavin and thiamin in foods. Food Chem., 7, 77-80.

"The Infant Formula Act of 1980". (P L 96-359, 26 sept. 1980), United States Statutes at Large 94, pp. 1190-1195.

Toma, R. B., \& Tabekhia, M. M., (1979). High performance liquid chromatographic analysis of B-vitamins in rice and rice products .J. Food Sci., 44, 263-66.

Tsai, S. W., Tsou, S. C. S., \& Simpson, K. L., (1989). Reversed phase flash column analysis of provitamin A carotenoids. J. Micronutr. Anal., 5, 171-79.

Vanderslice, J. T., \& Huang, M. A., (1986). Liquid chromatography analysis of thiamin and its phosphates in food products using improlium as an internal standard. J. Micronutr. Anal., 2, 189-99.

Wehling, R., \& Wetzel, D., (1984). Simultaneous determination of pyridoxine, riboflavin and thiamin in fortified cereal products by high performance liquid 
chromatography. J. agric. Food Chem., 6, 1326-30.

Wills, R. B. H., Shaw, C. G., \& Day, W. R., (1977). Analysis of water soluble vitamins by High performance liquid chromatography. J. Chromatog. Sci., 15, 262-66.

Wills, R. B. H., Wimalasiri, P., \& Greenfield, H., (1985). Comprarative determination of thiamin and riboflavin in foods by high performance liquid chromatography and fluorometric methods. J. Micronutr. Anal., 1, 23-29.

Wimalasiri, P., and Wills, R. B. H., (1985). Simultaneous analysis of thiamin and riboflavin in foods by High performance liquid chromatography. J. chromatogr., 318, 412-16. 
APPENDIX A

IITERATURE REVIEW

$-46-$ 
Thiamin (vitamin $B_{1}$ ) is essential in the nutrition of humans. Thiamin deficiency in the human diet causes a condition known as beriberi. This is characterized by loss of appetite and weight (Lehninger, 1982). Polyneuritis involving degeneration of the pripheral nerves, coupled with high concentration of lactate and pyruvate in the blood, may develop in the latter stage of deficiency (Ellefson, 1985).

Thiamin pyrophosphokinase metabolizes thiamin to thiamin pyrophosphate (TPP) in animal cells (Kawasaki and Sanemori, 1985). TPP, the coenzyme form of the vitamin, plays an important role in glycolysis and the glycolytic pathway, the citric acid cycle and the pentose pathway (Lamden, 1972).

The Recommended Daily Allowance (RDA) of thiamin is from 1.0 to $1.5 \mathrm{mg} /$ day for adults.

The thiamin molecule consists of a pyrimidine compound and a thiazole compound connected by a methylene group. In pure form thiamin is a white crystaline powder with a characteristic odor and slightly bitter taste. It is hygroscopic, easily soluble in water, less soluble in 
methanol, nearly insoluble in ethanol, and insoluble in ether, benzene, chloroform and hexane.

Thiamin in dry form is stable to the atmospheric oxidation. In aqueous form it is sensitive to oxidation and reduction. At $\mathrm{pH}$ below 5 thiamin solution can stand sterilization at $110^{\circ} \mathrm{C}$, however, at $\mathrm{pH}$ above 5 thiamin is rapidly destroyed when the solution is heated to this temperature.

As shown in figure $A-1$. vitamin $B_{1}$ occurs in biological materials in the free form, as the thiamin monophosphate, thiamin pyrophosphate and thiamin triphosphate (Lamden, 1972). In plant tissue thiamin is mostly found in the free form, while the most abundant form in animal tissue is the pyrophosphate.

Thiamin is found in many plants. Fruit and vegetables contain small amounts, while the outside coats of grains have high amount of the vitamin. In animals, thiamin is found in various organs ( heart, liver, kidney, and brain) (Rosenberg, 1942).

Foods like nuts, pork, yeast and cereal germs are particularly rich in thiamin (Ellefson, 1985). Products 
Figure A.1 structures of Thiamin and its related compounds. 
$\left.\right|_{\mathrm{N}}$

Thiamin

Thlochrome<smiles>Cc1ncc(C[n+]2csc(CCOP)c2C)c(N)n1</smiles>

R : $-H$

$: \begin{aligned} & \text { II } \\ & -\stackrel{P}{\mathbf{P}}-\mathrm{OH} \\ & \mathrm{OH}_{\mathrm{H}}\end{aligned}$

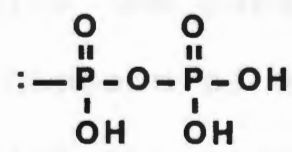

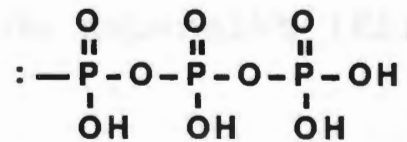

Thiamin

Thiamin monophosphate

Thiamin pyrophosphate

Thlamin trlphosphate 
such as white bread, white flour, breakfast cereals, spaghetti, and macaroni are low in vitamin $B_{1}$ and are usually enriched or fortified (Lamden, 1972).

Animal assays were the first methods developed to measure thiamin contents in food. Animals that have been utilized are the chick, the pigeon and the rat (Lamden, 1972). The most used animal assays were growth measurements and curative tests (Ellefson, 1985). Animal assays are useful because they are specific for thiamin and are of important in determining all forms of thiamin that are physiologically available to animals. Also, because animal assays determine all biological forms of thiamin, there is no need for the extraction or pretreatment of the sample as required by other methods (Lamden, 1972).

The main disadvantages of these assays are time required and high cost. The growth test takes 6 to 8 weeks, while the curative test is slightly faster. The use of large numbers of animals and specially prepared diet, coupled with the long feeding time needed, caused these tests to be expensive (Ellefson, 1985).

Different microbiological methods have been employed in thiamine determination. Fermentation and the growth of 
or acid production by bacteria, yeasts, molds or fungi have been used. These methods are less expensive, faster, more sensitive, and give more reproducible results than animal methods. An microbiological assay takes from 4 hours to 3 days to complete. The main disadvantage of these methods is the effect of other materials such as the breakdown products of thiamin The microorganisms respond to these products in the same manner as thiamin, thus, these methods are not often reproducible (Ellefson, 1985).

Most of the colorimetric methods suggested for determination of thiamin depend on the reaction of the vitamin with a diazoitized reagent.

The most successful reagent was diazotized p-aminoacetophenon. It was introduced by Prebluda and McCollum (1939). In alkaline solutions the reagent reacts with the thiazole portion of thiamin to form a purple-red color. The colored compound produced is insoluble in water. This reaction was developed into a satisfactory quantitative method by Melnick and Field (1939). They described a procedure for the extraction of the purple-red colored compound with exylene, and the purification and concentration of thiamin by means of zeolite adsorption. It is the most widely used colorimetric method for thiamin determination. 
In colorimetric method larger amount of thiamin (20 $100 \mu \mathrm{g}$ ) is required in the test sample than for the thiochrome method. The determination although specific, is rather complex, tedious and time consuming (Mickelsen and Yamamoto, 1958).

In thiamin determination both colorimetric and thiochrome methods have similar initial steps. These include: extraction with dilute hydrochloric acid or sulfuric acid; hydrolysis of the phosphate esters of thiamin by phosphatase containing enzyme; adsorption on base or ion exchange column and elution of thiamin (Lamden, 1972).

Thiochrome method for thiamin determination had its beginning in the work of Peters in 1935, who discovered that the oxidation of thiamin resulted in its conversion to a strongly blue fluorescent material which was called thiochrome. Jansen (1936) was the first to utilize this property of thiamin as the basis for a quantitative estimation of thiamin. Hennessy and cercedo (1939) improved the method by introducing an enzyme for the hydrolysis of the phosphate esters of thiamin and used a base exchange zeolite to separate thiamin from impurities which interfere in the determination. Although their 
procedure was studied and occasionally modified, it is still the basis for thiochrome method. Recently Bio-Rex 70 ion exchange resin has replaced Decalso resin used in the purification step (Effelson et al, 1981).

The thiochrome method is the standard method of the Association of official Analytical Chemists (AOAC). The manual thiochrome method will measure 1 to $20 \mu \mathrm{g}$ of thiamin in the test sample (Lamden, 1972). The advantages of this method over the biological and colorimetric methods are: rapid analysis, good precision and a wide range of applications (Ellefson, 1981)

Gas Chromatography (GC) was also applied for thiamin measurment. A nitrogen-phosphorus detector has been used to detect thiamin in meat, vegetables and cereals (Echols et al., 1983) and in milk (Echols et al., 1985). Advantages of the GC are simplicity of procedure, ease of standarization, and lack of cleanup. However, disadvantages of the of the GC procedure are the relatively large amount of sample needed, the high cost of the instrumentation and the long time required to run a GC analysis (Echols et al., 1983).

In recent years there have been an increase in the number of analytical methods utilizing high performance 
liquid chromatography (HPLC) for thiamin determination in food. HPLC methods usually utilize the same acid extraction and enzyme hydrolysis used in the AOAC method, followed by protein precipitation with trichloroacetic acid when oxidation to thiochrome was adopted (Fingals and Faulks, 1984; Hurst et al., 1983; Ohta et al.,1984). However, when the purpose was to measure non-derivatized thiamin, acid extraction followed by a clean-up and concentration step through disposable columns (Hilker and Clifford, 1982), decreased the analysis time. This extraction technique allowed the detection of thiamin phosphate esters as well as free thiamin by a UV detector (Hilker and Clifford, 1982; Kimura et al., 1982; Panijban et al., 1982; Vanderslice and Huang, 1986).

The reversed phase (RP), using $C_{18}$ and $C_{8}$ is the most widely employed HPLC system for thiamin analysis (Polsello and Rizzolo, 1986). On the other hand different mobile phases were utilized, such as organic solvents (Ang and Moseley, 1980; Fingals and Faulks, 1984), ion pairing (Augustin, 1984; Kamman et al., 1980; Skurray, 1981; Toma and Tabekhia, 1979), organic aqueous buffer mixtures ( Fellman et al., 1982; Hilker and Cliffer, 1982), and aqueous buffer eluents (Ohta et al., 1984). Vitamin $\mathrm{B}_{1}$ was detected and measured either directly as thiamin by UV 
detection (Ayi et al., 1985; Hilker and Clifford, 1982; Kamman et al., 1980; Toma and Tabekhia, 1979; Vanderslice and Huang, 1986), or indirectly as thiochrome, by flourimetric detection, which can be obtained after pre column (Ang and Moseley, 1980; Augustin, 1984; Botticher and Botticher, 1986; Fellman et al., 1982; Fingals and Faulks, 1984; Skurray, 1981), or post column (Hurst et al., 1983; Ohta et al., 1984; Vanderslice and Huang, 1986) oxidation.

The HPLC method has many advantages over the manual AOAC thiochrome method such as direct analysis without derivatization, simultaneous determination of different vitamins in a single analysis, a reduced analysis time and good precision and accuracy (Polsello and Rizzolo, 1986). However, the initial capital cost and subsequent recurrent cost of HPLC instrumentation are relatively high and a skilled operator is needed (Fingals and Faulks, 1987).

The RP $C_{18}(50 \mu)$ packed into an open column has been used in this laboratory to separate carotene (Tsai et al, 1989) and retinol (Al-Abdulaly and Simpson, 1989) from various foods. Furthermore, it was used to separate riboflavin, a water soluble vitamin, from milk and milk products (Saibu, 1988). 


\section{BIBLIOGRAPHY}

Agricultural Research Service, (1976). Composition of Foods, Agricultural Handbook No. 8-1, Consumer and Food Economics Institute, Agricultural Research Service USDA, Washignton D.C.

Al-Abdulaly, A. B., \& Simpson, K. L., (1989). Reversed-phase flash column chromatography for the determination of retinol in some foods. J. Micronutr. Anal., 5, 161-69.

Andrews, J. S., \& Nordgren, R., (1941). The application of the thiochrome method to the thiamin analysis of cereals and cereal products. Cereal Chem., 18, 686-95.

Ang, C. Y. W., \& Moseley, F. A., (1980). Determination of thiamin and riboflavin in meat and meat products by HPLC. J. Agric. Food Chem., 28, 483-86.

AOAC. (1984). Official Methods of Analysis (14th ed.), Assoc. Off. Anal. Chem. Arlington, VA., 43.024-43.029.

Augustin, J.,(1984). Simultaneous determination of thiamin 
and riboflavin in foods by liquid chromatography. J. Assoc. Off. Anal. Chem. 67, 1012-15.

Ayi, B. K., Yuhas, D. M., Moffett, K. S., Joyce, D. M., \& Deangelis, N. J., (1985). Liquid chromatography determination of thiamin in infant formula products by using Ultraviolet detection. J. Assoc. Off. Anal. Chem. $68,1087-92$.

Beadle, B. W., Greenwood, D. A., \& Kraybill, H. R., (1943). Stability of thiamin to heat. J. Biol.Chem., 149, $339-47$.

Bio Rad, Guide to ion exchange, Catalog No. 140-9997. Bio Rad Laboratories, Richmond, CA.

Botticher, B., \& Botticher, D., (1986). Simple rapid determination of thiamin by HPLC method in foods, body fluids, Urine and faeces. Int. J. Vit. Res., 56, 155-59.

Brown, E. B., Hamm, J. C., \& Harrison, H. E., (1943). Comparison of thiamin values by chemical and bioassay methods. J. Biol. Chem., 151, 153-61.

Clausen, D. F., \& Brown, R. E., (1943). Determination of thiamin in bread by the thiochrome method. Ind. Eng. Chem. 
Anal. Ed., 15, 100-101.

Conner, R. T., \& Straub, G. J., (1941). Determination of thiamin by thiochrome reaction. Ind. Eng. Chem. Anal. Ed., $13,380-84$.

Defibaugh, P. W., (1987). Evaluation of selected enzymes for thiamin determination. J Assoc. Off. Anal. Chem., 70, $514-17$.

Defibaugh, P. W., Smith, J. S., \& Weeks, C. A., (1977). Assay of thiamin in foods, using manual and semiautomated fluorometric and microbiological methods. J. Assoc. Off. Anal. Chem., 60, 522-27.

Echols, R. E., Miller, R. H., winzer, W., Carmen, D. J., \& Ireland, Y. R., (1983). Gas chromatographic determination of thiamin in meats, vegetables and cereals with a nitrogen-phosphorus detector. J. Chromatography., 262, $257-63$.

Echols, R. E., Miller, R. H., \& Foster, W., (1986). Analysis of thiamin in milk by gas chromatography and the nitrogen-phosphorus detector. J. Dairy Sci., 69, 1246-49.

Ellefson, W. C., (1985). "Thiamin", in Methods of vitamin 
assay, 4th. Ed. J. Augustin et al. Editors, John WILEY \& sons. p. 349-63.

Ellefson, W. C., Richter, E., Adams, M., \& Baillies, N. H., (1981). Evaluation of ion exchange resins and various enzymes in thiamin analysis. J. Assoc. Off. Anal. Chem., $64,1336-38$.

Fellman, J. K., Artz, W. E., Tassinari, P. D., Cole, C. L., \& Augustin, J., (1982). Simultaneous determination of thiamin and riboflavin in selected foods by high performance liquid chromatography. J. Food Sci., 47, 2048-50.

Fingals, P. M., \& Faulks, R. M., (1987). Critical review of HPLC methods for the determination of thiamin, riboflavin and niacin in food. J. Micronutr. Anal., 3, 251-83.

Fingals, P. M., \& Faulks, R. M., (1984). The HPLC analysis of thiamin and riboflavin in potatoes. Food Chem., 15, 37-44 .

Halliday, N., \& Deuel, H., (1941). The presence of free and combined thiamin in milk. J. Biol. Chem., 140, 55-61. 
Hennessy, D. J., \& Cerecedo, L. R., (1939). The determination of free and phosphorylated thiamin by a modified thiochrome assay. J. Am. Chem. Soc. 61, 179-83.

Hilker, D. M., \& Clifford, A. J., (1982). Thiamin analysis and separation of thiamin phosphate esters by high performance liquid chromatography. J. Chromatogr., $231,433-438$.

Hurst, W. J., Mckim, J. M., \& Martin, R. A., (1983). The HPLC analysis of thiamin in milk chocolate. Int. J. vit. Res., 53, 239-42.

Jansen, B. C. P., (1936). A chemical determination of aneurin (vitamin $B_{1}$ ) by the thiochrome reaction. Rec. Trav. Chim., 55, 1046-52.

Kamman, J. F., Labuza, T. P., \& Warthesen, J. J., (1980) . Thiamin and riboflavin analysis by high performance liquid chromatography. J. Food Sci., 45, 1497-99.

Kawasaki, t., and Sanemori, H., (1985). "Vitamin B : $_{1}$ Thiamines" in Modern chromatographic analysis of the vitamins, 1st ed. Deleenheer, A. P. et al. Editors, Marcel Dekker, Inc. p. 385-411. 
Kimura, M., Panijpan, B., \& Itokawa, Y., (1982). separation and determination of thiamin and its phosphate esters by reversed phase high performance liquid chromatography. J . Chromatogr., 245, 141-43.

Kinnersley, H. W., O`Brien, J. R., \& Peters, R. A., (1935). The properties of blue fluorescent substances formed by oxidation of vitamin $B_{1}$ (quinochromes). Biochem. J., 29, 2369-84.

Lamden, M. P., (1972). "Thiamin" in The vitamins, chemistry, physiology, pathology, methods. vol. V., 2nd Ed., Sebrell, W. H., and Harris, R. S. Editors. Academic press. p. 110-120.

Lehninger, A. L., (1982). Principles of Biochemistry, 1st. ed. Worth publishers, Inc., p. 252-54.

Loofbourow, J. R., \& Harris, R. S., (1942). The evaluation of fluorophotometers to be used in the thiochrome assay for vitamin $B_{1}$. Cereal Chem., 19, 151-68.

MacBride, D. E., \& Wyatt, C. J., (1983). Evaluation of a modified AOAC determination for thiamin and riboflavin in foods. J. Food Sci., 48, 748-50. 
Martin, J. I., Phifer, E. C., Hines, D. M., Hamill, T. W., Young, E. R., Eitenmiller, R. R., \& Soliman, A. M., (1987). Thiamin, riboflavin and ascorbic acid levels in infant formulas manufactured in the United States. J. Food Comp. Anal., 1, 76-80.

Mauro, D. J., \& Wetzed, D. L., (1984). Simultaneous determination of thiamin and riboflavin in enriched cereal based products by high performance liquid chromatography using selective detection. J. Chromatogr., $299,281-87$.

McFarlane, W. D., \& Chapman, R. A., (1941). An improved thiochrome method for the determination of vitamin $B_{1}$. Can. J. Res., 19B, 136-42.

Melnick, D., \& Field, H., (1939). Chemical determination of vitamin $B_{1}$, method for estimation of the thiamin content of biological materials with the diazotized p-amoinoacetophenone reagent. J. Biol. Chem. 127, 515-30.

Melnick, D., and Field, H., (1939). Chemical determination of vitamin $B_{1}$, quantitative enzymic conversion of cocarboxylase (thiamin pyrophosphate) to the free vitamin. J. Biol. Chem. 127: 531-540. 
Mickelsen, O., \& Yamamoto, R. S., (1958). Methods for the determination of Thiamin. Methods Biochem. Anal. 6, 191-257.

National Research Council, (1989). Recommended Dietary Allowances, 10th ed., Commitee on Dietary Allowances, Food and Nutrition Board, Commission on Life Sciences, National Research Council, National Academy Press, Washignton D.C.

Nicolson, I. A., Macrae, R., \& Richardson, D. P., (1984). Comparative assessment of HPLC methods for the determination of ascorbic acid and thiamin in foods. Analyst, 109, 267-71.

Ohta, H., Baba, T., \& Suzuki, Y., (1984). High performance liquid chromatographic analysis of thiamin in rice flour with flourimetric post column derivatization. J. Chromatogr., 284, 281-84.

Panijpan, B., Kimura, M., and Itokawa, Y., (1982). Separation of thiamin and its common degradation and oxidation products by HPLC. J. Chromatogr., 245, 144-146.

Pelletier, O., \& Madere, R., (1975). Comparison of automated and manual procedures for determining thiamin and riboflavin in foods. J. Food. Sci., 40, 374-79. 
Peters, R. A., (1935). Vitamin $B_{1}$ and blue fluorescent compounds. Nature, 135, 107.

Pippen, E. L., \& Potter, A. L., (1975). Quantitating the recovery of thiamin (Vitamin $B_{1}$ ) from Decalso in the thiochrome method for the determination thiamin. J. Agric. Food Chem., 23, 523-26.

Polsello, A., \& Rizzolo, A., (1986). Applications of HPLC to the determination of water-soluble vitamins in foods. (a Review 1981-1985) J. Micronutr. Anal., 2, 153-87.

Prebluda, H. J., \& Mecollum, E. V., (1939). A chemical reagent for thiamin. J. Biol. Chim., 127, 495-503.

Rindi, G., \& DeGuiseppo, L., (1961). A new chromatographic method for the determination of thiamin and its mono-, diand tri-phosphates in animal tissues. Biochem. J., 78, 602-06.

Rosenberg, h. R., (1942). Chemistry and physiology of the vitamins. Interscience, New York, p. 99-150.

Saibu L. O., (1988). Development of a revese-phase open column method of quantifying riboflavin in milk. M.S. 
thesis. Department of food science and nutrition at URI.

Sebecic, B., \& Dragojevic, I. V., (1986). An improved simple procedure for the determination of thiamin in food. Die Nahrung., 5, 527-32.

Skurray, G. R., (1981). A rapid method for selectively determining small amounts of niacin, riboflavin and thiamin in foods. Food Chem., 7, 77-80.

"The Infant Formula Act of 1980". (P L 96-359, 26 sept. 1980), United States Statutes at Large 94, pp. 1190-1195.

Toma, R. B., \& Tabekhia, M. M., (1979). High performance liquid chromatographic analysis of B-vitamins in rice and rice products .J. Food Sci., 44, 263-66.

Tsai, S. W., Tsou, S. C. S., \& Simpson, K. L., (1989). Reversed phase flash column analysis of provitamin A carotenoids. J. Micronutr. Anal., 5, 171-79.

Vanderslice, J. T., \& Huang, M. A., (1986). Liquid chromatography analysis of thiamin and its phosphates in food products using improlium as an internal standard. J. Micronutr. Anal., 2, 189-99. 
Van De Weerdhof, T., Wiersum, M. L., \& Reissenweber, H., (1973). Application of liquid chromatography in food analysis. J. Chromatogr., 83, 455-60.

Watson, H. A., (1946). Study of some factors influencing the oxidation of thiamin to thiochrome. Cereal Chem., 23, $166-77$.

Wehling, R., \& Wetzel, D., (1984). Simultaneous determination of pyridoxine, riboflavin and thiamin in fortified cereal products by high performance liquid chromatography. J. agric. Food Chem., 6, 1326-30.

Williams, R. C., Baker, D. R., \& Schmit, J. A., (1973). Analysis of water soluble vitamins by high speed ion exchange chromatography. J. Chromatogr. Sci., 11, 618-24.

Wills, R. B. H., Shaw, C. G., \& Day, W. R., (1977). Analysis of water soluble vitamins by High performance liquid chromatography. J. Chromatog. Sci., 15, 262-66.

Wills, R. B. H., Wimalasiri, P., \& Greenfield, H., (1985). Comparative determination of thiamin and riboflavin in foods by high performance liquid chromatography and fluorometric methods. J. Micronutr. Anal., 1, 23-29. 
Wimalasiri, P., and Wills, R. B. H., (1985). Simultaneous analysis of thiamin and riboflavin in foods by High performance liquid chromatography. J. chromatogr., 318, 412-16. 